\title{
Svetlana Kmecová
}

FILOZOFSKA FAKULTETA

Univerza Komenskega v BratisLaVI

BratisLAVA, SLOVAŠKA

svetlanaluhova@hotmail.com

https://doi.org/10.17234/9789531755139.13

\section{SVET PTIC V LUČI SLOVAŠKE IN SLOVENSKE FRAZEOLOGIJE}

\begin{abstract}
V prispevku so obravnavane slovaške in slovenske stalne besedne zveze, v sestavi katerih so poimenovanja za posamezno vrsto ptic, ki živijo v naravi v zmernem geografskem pasu, kjer se nahajata tudi Slovenija in Slovaška. V raziskavo so poleg osnovnih poimenovanj vključene tudi njihove izpeljane pridevniške in glagolske oblike. Avtorica omenja tudi simboliko, ki jo nosijo posamezne vrste ptic, saj ima le-ta $\mathrm{v}$ mnogih primerih pomembno vlogo pri razlaganju motivacije nastanka frazemov. V nadaljevanju ugotavlja pojavljanje raziskovanega tipa sestavin $\mathrm{v}$ prostih, terminoloških in leksikaliziranih besednih zvezah ter primerja njihovo prisotnost v frazemih na osnovi pomenskega (vsebinskega) ujemanja, torej z vidika frazeološke ekvivalentnosti. Ugotavlja, da je zastopanost frazemov s tako opredeljenimi sestavinami zelo velika in raznolika ter da so z vidika slovaško-slovenske primerjalne frazeologije zanimivi zlasti primeri delne ekvivalentnosti, še posebej pa frazemi, ki v drugem obravnavanem jeziku nimajo ustreznice.
\end{abstract}

Ključne besede: frazem, slovaška frazeologija, slovenska frazeologija, frazemska sestavina, frazeološka ekvivalentnost

\section{Uvod}

1.1 Slovník slovenského jazyka definira ptice kot „,vretenčarje s perjem in sposobnostjo letenja“" (SSJ 1965: 190). Prav zaradi te sposobnosti, ki pticam daje skoraj absolutno svobodo, jim omogoča neomejeno gibanje, hkrati pa jim daje možnost, da vidijo svet z višine, so med vsemi živalmi vedno imele poseben položaj. Za razliko od žuželk, ki sicer spadajo v drugo skupino živali, imajo pa sposobnost letenja in vzbujajo pri ljudeh pogosto negativne občutke, so ptice v simboliki in mitologiji večinoma nosilke pozitivnih lastnosti. Simbolizirajo človekovo hrepenenje po osvoboditvi od zemeljske težnosti, po doseganju višjih sfer, obenem pa so tudi simbol svobode in prostosti (Biedermann 1992: 342). Pogosto nastopajo v bajkah, povestih, pravljicah in pesmih, so ognjene ali zlate. Upodabljali so jih umetniki, so del grbov pomembnih plemiških rodbin, v sedanjosti pa se nahajajo v logotipih različnih organizacij in podjetij. ${ }^{1}$ Iz njihovih

Na primer na Slovaškem ÚL'UV - Center ljudske umetnostne izdelave, nagrada Bela vrana, Slovaška narodna stranka, v Sloveniji ustvarjalni studio Zlata ptica, podjetje za izobraževanje, usposabljanje in izpopolnjevanje Tangens in čokoladnica Rajska ptica. 
poimenovanj so bili zelo pogosto oblikovani ali izpeljani priimki, ${ }^{2}$ najdemo jih v imenih mest, vasi, rek in v drugih toponimih. ${ }^{3}$ Predstavljajo zelo raznoliko skupino živali, razlikujejo se po velikosti, barvi, glasu, s katerim se oglašajo, prehranjevalnih navadah in vedenju. Lastnosti in navade posameznih vrst ptic so ljudje pozorno opazovali, človekovo zaznavanje in dojemanje ter njegove fizične in kulturne izkušnje pa so se postopoma začele odražati tudi v posameznih jezikih, in sicer $\mathrm{v}$ obliki stalnih besednih ter stavčnih zvez s slikovitim oziroma prenesenim pomenom.

1.2 $\mathrm{V}$ prvem delu prispevka se bomo osredotočili na slovaške in slovenske stalne besedne zveze, v katerih se nahajajo leksikalne enote vták (vtáčik), vtáč : ptič (ptiček), ptičji, $\mathrm{v}$ drugem delu prispevka pa bomo obravnavali enote, katerih sestavine predstavljajo najpogostejša poimenovanja vrst ptic. Že kratek vpogled v zbrano frazeološko gradivo dokazuje, da je korpus frazeoloških enot, ki pozna tovrstno leksikalno zapolnitev frazeoloških enot, kvantitativno obsežen in pester. Kot ugotavlja Krošláková (1997: 106), se večje število frazeoloških enot navezuje prav na domače živali. To zagotovo velja tudi za domače ptice, vendar se v tem prispevku ne bomo osredotočili na frazeološke enote, ki bi vključevale to skupino ptic. Predmet naše raziskave bomo omejili na ptice, živeče v naravi, konkretno v srednjeevropskem, zmernem geografskem pasu, se pravi na ozemlju, kjer se nahajata tudi Slovaška in Slovenija. Pri tem se bomo osredotočili samo na pojavljanje sestavin znotraj sestave nestavčnih frazemov.

1.3 Gradivo za našo raziskavo smo pridobili v glavnem iz frazeoloških in enojezičnih razlagalnih slovarjev, obenem pa tudi iz nekaterih drugih dostopnih (večinoma spletnih) virov. Za slovaški jezik so predstavljali izhodišče predvsem: Slovnik súčasného slovenského jazyka (v nadaljevanju SSSJ), Slovník slovenského jazyka (v nadaljevanju SSJ), Krátky slovnik slovenského jazyka (v nadaljevanju KSSJ) in Malý frazeologický slovnik (v nadaljevanju MFS). Slovenske primere smo črpali predvsem iz: Slovarja slovenskih frazemov (v nadaljevanju SSF) ${ }^{4}$, Slovarja slovenskega knjižnega jezika (v nadaljevanju SSKJ), knjig Janeza Kebra Živali v prispodobah 1, 2 in korpusa Gigafida. Pri analizi primerjalnih frazemov smo izhajali tudi iz devetjezičnega slovarja primerjalnih frazemov Hrvatsko-slavenski rječnik poredbenih frazema (v nadaljevanju HSRPF).

1.4 Raziskava, ki je povezana z zastopanostjo posameznih poimenovanj različnih živali v frazeoloških fondih posameznih jezikov, v slovaški in slovenski frazeologiji ni nobena novost, je pa res, da bi težko trdili, da so frazemi z živalskim poimenovanjem v svoji sestavi izčrpno opisani.

$\overline{2}$ Na primer na Slovaškem priimki Holub, Straka, Slávik, Orlovský, Sokolovský, v Sloveniji priimki Grlica, Golob, Vrabec, Sovič, Sokolič itd.

3 Na primer slovaško mesto Vranov nad Toplou, vasi Vyšný in Nižný Orlik, Jastrabie, v Sloveniji pa vasi Golobinjek, Orla Vas, Vransko itd.

$4 \quad$ Slovar slovenskih frazemov je izšel leta 2011 in zajema več kot 5000 frazeoloških enot. Čeprav imajo slovenski jezikoslovci glede omenjenega slovarja in njegovega poskusnega zvezka več zadržkov (o tem tudi Erika Kržišnik (2004: 199-208), Jürgen Petermann, Erika Kržišnik (2004: 345-352) in Polona Gantar (2013: 145-156), je za nas predstavljal pomembno izvirno gradivo o pojavljanju raziskovanega tipa frazemov. 
V slovaški frazeologiji se je s t. i. živalsko frazeologijo ukvarjal Jozef Škultéty v svoji študiji Názvy cicavcov v slovenských ustálených prirovnaniach (1989). Poleg zastopanosti konkretnih vrst sesalcev $\mathrm{v}$ primerjalnih frazemih avtor raziskuje njihovo notranjo povezanost $\mathrm{v}$ primerjalnem delu $\mathrm{z}$ glagoli in s pridevniki v primerjalni osnovi ter jih analizira s stilističnega, onomastično-semantičnega in konfrontacijskega vidika.

Ema Krošláková v članku Frazeologické prirovnania so zoonymickým komponentom (1997) ugotavlja, da je ena od temeljnih lastnosti tovrstnih frazemov ekspresivnost, na osnovi katere jih lahko razdelimo na dve veliki pomenski enoti oziroma makropolji, opredeljeni s splošno semo. Na eni strani je negativno vrednotenje ljudi in pojavov, na drugi strani pa pozitivno vrednotenje le-teh. Krošláková (1997: 105) ugotavlja, da lahko obe makropolji razvrstimo tudi glede na biološko klasifikacijo živalskega sveta. Avtorica v nadaljevanju piše tudi o semantični motivaciji primerjalnih frazemov in poudarja, da ima pri tem poleg življenjskih izkušenj ter ljudskih in verskih tradicij pomembno vlogo tudi obstoječa tradicionalna simbolika živali.

Barbora Mečiarová v prispevku Zoonymické komponenty pes a mačka v slovenskej a bulharskej frazeológii (2002) preučuje dve verjetno najpogostejši poimenovanji za živali, ki sta zastopani v sestavi frazemov, pa tudi njun medsebojni, tradicionalno sovražni odnos, in njuno podobo v slovaških in bolgarskih frazeoloških enotah. Ugotavlja, da sta pes in mačka nosilca ambivalentnih lastnosti, zaradi česar tudi v frazeologiji nastopata $\mathrm{v}$ povezavi s pozitivnimi in $\mathrm{z}$ negativnimi lastnostmi (Mečiarová 2002: 268).

V slovenski frazeologiji se je s problematiko živalskega sveta v frazeologiji podrobno ukvarjal Janez Keber. V delih Slovenske živali v prispodobah 1 in 2 (1996, 1998) obravnava metaforiko in simboliko, ki sta povezani s posameznimi živalskimi vrstami ter frazeme, ki vsebujejo njihova poimenovanja, pri čemer jih analizira $\mathrm{z}$ vidika semantike, razlaga motivacijo njihovega nastanka in s citati iz knjižnih in drugih virov prikazuje njihovo prisotnost v slovenskem jeziku. Skupaj predstavlja „zgodbe“ 85 živalskih vrst, med njimi tudi več kot desetih vrst ptic. Frazeme, ki vsebujejo poimenovanja živali, obravnava še v drugih delih, na primer Živalske metafore kot vir za imena, vzdevke in priimke (1999), delno tudi v članku Razlaganje izvora slovenskih frazemov (2001).

$\mathrm{S}$ konfrontacijo slovenskih in slovaških primerjalnih frazemov, ki imajo v svoji zgradbi kot sestavino poimenovanja nekaterih vrst žuželk, se je v članku Najbolj razširjene žuželke v primerjalnih frazemih v slovenščini in slovaščini (2001) ukvarjala Darija Jakše. Ugotavlja, da v obeh jezikih obstaja veliko ekvivalentnih primerjalnih frazemov z omenjeno sestavino, hkrati pa tudi veliko število takšnih, ki v enem od jezikov nimajo ustreznice. Po avtoričinem mnenju je to posledica genetske in geografske bližine jezikov, hkrati pa relativno samostojnega razvoja obeh jezikov.

$\mathrm{Z}$ nekaterimi frazemi, ki imajo v svoji sestavi živalsko sestavino, sta se v slovenskem jezikoslovju med drugim ukvarjala tudi Erika Kržišnik v članku Biblične stalne zveze v slovarju slovenskega knjižnega jezika in v slovenskem jeziku (2000) in Marko Snoj v članku Frazemi v luči etimologije: metoda in praksa (2013). 


\section{Frazemi s sestavinami vták (vtáčik), vtáčí - ptič (ptiček), ptičji}

2.1 Leksikalna enota $v t a ́ k$, ki ima v slovenščini ekvivalent v samostalniku moškega spola ptič (pogovorno tič) in ženskega spola ptica (pogovorno tica), je v SSJ in SSKJ opisana kot „vretenčar s perjem“ (SSJ 1965: 190; definicije iz slovaških slovarjev navajamo v lastnem prevodu) oziroma ,žival, pokrita s perjem“ (SSKJ 1994: 1095). SSJ eksplicitno navaja tudi sposobnost letenja, medtem ko v SSKJ ta sposobnost ni navedena, omenjajo pa se peruti in kljun. Izpeljanki iz samostalnikov vták/ptič (tič), ptica (tica) so pridevniki vtáči/ptičji. Te leksikalne enote se pojavljajo v prostih besednih zvezah, na primer v slovaščini vtáčí spev, vtáčie hniezdo, vtáčie krídla in v slovenščini ptičje petje, ptičje gnezdo, ptičje peruti itd. Lahko so tudi del terminoloških besednih zvez, na primer slovaške stahovavý vták, spevavý vták, dravý vták s slovenskimi ustreznicami ptica selivka, ptica pevka, ptica ujeda in podobno. Pogosto so tudi del botanične terminologije, v slovaščini na primer vtáči zob, čerešña vtáčia, stavikrv vtácíl, v slovenščini ptičja dresen, ptičji kljunček, ptičje mleko idr. SSJ navaja, da lahko v prenesenem pomenu ali šaljivo z besedo vták poimenujemo 'nemirnega, tavajočega človeka' (SSJ 1965: 190), za razliko od tega pa je $\mathrm{v}$ SSKJ pod drugim pomenom besede ptič (tič) navedeno (ekspresivno, najpogosteje s prilastkom) 'iznajdljiv, prebrisan človek' (SSKJ 1994: 1095) oz. pri besedi ptica (tica) 'iznajdljiva, prebrisana ženska' (SSKJ 1994: 1095), kar pomensko bolj ustreza slovaški frazeološki enoti dobrý (pekný) vták (vtáčik). V slovaški in slovenski gastronomiji je vtáčik znan kot jed iz zvite rezine mesa, v slovaščini najpogosteje španielsky vtáčik, v slovenščini na primer telečji ptiček. V slovaščini, enako kot v slovenščini in mnogih drugih jezikih, v pogovornem jeziku obstaja vták v pomenu 'moški spolni ud', česar slovaški slovarji ne omenjajo, SSKJ pa navedeni pomen označuje s kvalifikatorjem evfemistično in $\mathrm{z}$ opombo, da lahko $\mathrm{v}$ tem pomenu uporabimo zgolj sestavino tič (SSKJ 1994: 1396).

2.2 Brezskrbno življenje, prostost in svoboda kot najpomembnejše značilnosti načina življenja ptic odražajo slovaški frazem byt' volný ako vták in njeni slovenski ustreznici živeti kakor ptica (ptič) pod nebom in biti prost kot ptiček na veji. $\mathrm{K}$ absolutnim frazeološkim ekvivalentom v obeh jezikih spadajo frazemi: ocelový vták - jeklena ptica (ptič) s pomenom 'letalo'; nočný vták - nočni ptič je preneseno poimenovanje za ‘človeka, ki v noči dolgo bedi, oz. dela'; vtáčia perspektiva - ptičja perspektiva je 'pogled z velike višine', v prenesenem pomenu tudi 'odstop'. Pri tem moramo opozoriti, da Janez Keber to zvezo razlaga zgolj kot frazem, $v$ slovaščini pa ni jasno umeščena med frazeme, saj jo prištevajo $\mathrm{k}$ besednim zvezam s prenesenim pomenom in je kot taka na meji frazeologije.

Eksistenco ekvivalentnih frazeoloških enot $\mathrm{v}$ obeh jezikih, pri čemer je $\mathrm{v}$ enem od njiju ornitološka sestavina zamenjana s pomensko nadrejeno ali podrejeno leksikalno enoto, lahko zasledimo $\mathrm{v}$ ironičnem slovenskem frazemu biti ptičje pameti 'biti neumen, omejen'. Njegova slovaška ustreznica je frazem mat'slepači (kurací) rozum, pri čemer v slovenščini obstaja tudi popoln ekvivalent - frazem imeti kurjo pamet oz. njegova različica biti kurje pameti s sopomenko imeti vrabčjo pamet (vrabčje možgane). Omenimo naj še slovenski besednozvezni frazem ne tič ne miš, ki ima enako pomensko ustreznico tudi $\mathrm{v}$ slovaščini, ki ne vsebuje enake živalske sestavine, pač pa je v obliki ani ryba, ani rak. ${ }^{5}$

V slovenščini dobesedno ne riba ne rak. 


\section{Frazemi s sestavino kukučka - kukavica}

3.1 Kukučka - kukavica (lat. Cuculus) je v številnih kulturah predstavljala ,ptico duše“, prerokinjo prihodnosti ali znanilko pomladi. Boginja Hera je na žezlu imela kukavico, saj se je pred poroko z Zevsom le-ta spremenil v kukavico (Biedermann 1992: 152). Na Slovaškem so ljudje verjeli, da lahko s svojim kukanjem napove dolžino življenja ali dekletom naznani število let do poroke, v Sloveniji pa tudi to, da lahko človek v svojem življenju pričakuje denar.

SSSJ definira leksem kukučka kot „,zaščiteno, srednje veliko ptico selivko iz družine kukavic, ki se oglaša z značilnim glasom ku-ku, živi v svetlih gozdovih in vali jajca v tuja gnezda“" (SSSJ 2011: 845). Slovaška leksikalna enota kukučky je pogovorni izraz za kukučkové hodiny, v slovenščini ura s kukavico. Prenesena besedna zveza kukučie mlád'a in enobesedno ekspresivno poimenovanje kukúča na Slovaškem ponavadi označuje 'otroka, ki je vzgajan v tuji družini' (SSJ 1959: 789). Slovensko ekspresivno poimenovanje kukavica označuje 'tujega nezakonskega otroka', v preteklosti pa je bila tudi oznaka za 'boječega človeka' (SSKJ 1994: 465). V slovaščini je kukučka lúčna poimenovanje travniške zdravilne rastline (lat. Lychnis flos-cuculi), v slovenščini je to kukavičja lučka, kar je v češčini pod imenom kohoutek loučni. ${ }^{6}$

3.2 Omenjena kukavičja (slaba) navada, da podtika jajca v tuja gnezda, se v slovaščini odslikava v frazemu kukučkino (kukučie) vajce, ki ima prenesen pomen 'tuj, nelasten element; nekaj, kar nekam ne sodi oz. ne paše tja, kamor je bilo preneseno' (SSSJ 2011: 845). Njena slovenska ustreznica je kukavičje jajce, ki obstaja tudi v podobi glagolske zveze podtakniti komu kukavičje jajce.

\section{Frazemi s sestavinama sova, kuvik - sova, čuk}

4.1 Sova - sova (lat. Strix) je povezana s starogrško boginjo modrosti, sodstva, pravičnosti, poguma, strategije in umetnosti Pallas Ateno. V simboliki pa ima ambivalenten pomen. Na eni strani simbolizira modrost in učenost, $v$ ljudskih vražah pa je nosilka negativnih konotacij, zlasti zaradi njenega nočnega, samotarskega načina življenja, tihega leta in skovikajočega glasu, s čimer predstavlja odmik od duhovne svetlobe. To še posebej velja za kuvika - čuka (lat. Athene).

Po SSJ je sova vrsta roparske nočne ptice“, v drugem, slabšalnem pomenu pa 'čemeren, neprijeten človek, običajno ženska; psovka za takega človeka’ (SSJ 1964: 145). Človek, ki hodi pozno spat, pogosto poseda, bere, dela dolgo v noč se v slovaščini označuje z ekspresivnim izrazom nočná sova oziroma z njeno sestavinsko varianto nočný vták. ${ }^{7}$

SSKJ opisuje sovo ${ }^{8}$ obširneje kot ,večjo roparsko nočno ptico z mehkim perjem, okroglo glavo in velikimi očmi““ (SSKJ 1994: 1271). Podobno kot v slovaščini je tudi v slovenščini navedena leksikalna enota sova kot slabšalni izraz za 'grdo, neprijetno ose-

\footnotetext{
V slovenščini dobesedno travniški petelinček.

V slovenščini nočni ptič.

8 Kot zanimivost naj še navedemo, da je kratica SOVA oznaka za Slovensko obveščevalno-varnostno agencijo.
} 
bo' (SSKJ 1994: 1271), ki pa je lahko zgolj ženska. Človeka, ki hodi pozno spat, lahko v slovenščini prav tako poimenujemo sova oziroma tudi nočna sova ${ }^{9}$

4.2 Podoba sove, njene velike oči, pronicljiv pogled in našopirjeno perje so spodbudili nastanek frazemov hl'adiet' (pozerat', sediet') ako sova, byt' nadutý ako sova v pomenu 'biti namrščen, čemeren, nevljuden', kar v slovenščini ustreza frazemu gledati kakor sova. V obeh jezikih obstaja knjižni frazem nosit' sovy do Atén - nositi sove v Atene. Gre za internacionalni frazem, ki ima izvor v antiki in se uporablja v pomenu 'delati nekaj zaman' (KSSJ 2003: 685). Slovaški in slovenski frazeološki fond ima na voljo več sopomenskih frazemov domačega izvora, kot so na primer slovaški liat’ vodu do mora (Dunaja), nosit' drevo do hory (lesa), brat' (čerpat') vodu do sita in slovenski nositi vodo $v$ Savo, sipati pesek v morje, $v$ rešetu (z rešetom) vodo nositi (zajemati).

4.3 Posebna vrsta sove je kuvik - čuk, ne le v zoološkem smislu, ampak tudi z vidika simbolike in semantike, ki ju izraža. Po SSSJ je to „nočna ptica iz družine pravih sov, ki je razširjena v gozdovih in kulturnih predelih cele srednje Evrope" (SSSJ 2011: 865), kar je v KSSJ v oklepaju dopolnjeno z opombo 'po vraževerju napovedujoča smrt' (KSSJ 2003: 284). Drugi pomen leksema kuvik je torej ‘človek, ki napoveduje neugoden razvoj dogodkov, nesrečo ali pa je pesimist' (SSSJ 2011: 865). Glagol kuvikat' je nosilec pomena „oglašati se s kuvi“', pa tudi 'napovedovati nesrečo, strašiti' (KSSJ 2003: 284). V slovaščini obstaja starejša besedna zveza kuviči hlas in hlas kuvika s prenesenim pomenom 'govor, ki napoveduje nekaj slabega, nesrečo, konec, propad' (SSJ 1959: 797), h kateri nismo v slovenskih virih našli ustreznega ekvivalenta.

Po SSKJ ima samostalnik čuk v prenesenem pomenu prav tako negativne konotacije, pri čemer je poleg majhne nočne ptice, podobne sovi, tudi ekspresivno poimenovanje za 'čudnega, nekoliko omejenega človeka' (SSKJ 1994: 110), pridevnik čukast izraža pomen 'neprijazen, mrk', glagol čukati se poleg pomena „oglašati se z votlim, kratkim glasom" uporablja tudi v pomenu 'pripovedovati, navadno kaj neprijetnega' 10 (SSKJ 1994: 110), na tem mestu pa umanjka (vsaj v slovarjih) njegova opredelitev kot 'znanilca slabih vesti', ki jo poznamo v slovaščini. Toda ta pomen v slovenščini obstaja. SSKJ ga navaja na drugem mestu, in sicer pod geslom ptica, kjer se poleg drugega omenja mrtvaška ptica - po ljudskem verovanju 'ptica, ki napoveduje smrt, zlasti sova, čuk' (SSKJ 1994: 1095) in ga lahko zasledimo tudi v starejšem narečnem glagolskem frazemu čuk ga je izpel v pomenu ‘čaka ga smrt, umrl bo'. Leksem čukec, tj. pomanjševalnica besede čuk, se v slovenskem jeziku paradoksno uporablja kot ljubkovalno poimenovanje za 'otroka'.

4.4 V slovenščini obstajajo primerjalni frazemi gledati kot čuk, gledati kot čuk na palici, gledati kakor čuk z visokega kolca ${ }^{11} \mathrm{v}$ pomenu 'gledati jezno, neprijazno'. Motivacijo za njihov nastanek, poleg že omenjene zunanje podobe te vrste sove, je treba po

\footnotetext{
9 Antonimni izraz je v slovenščini frazem jutranja ptica s slovaško ustreznico ranné vtáča, v slovaščini je simbol zgodnjega vstajanja tudi škrjanček.

10 Podobno kot slovaško krákat', rapotat'.

11 Sinonim gledati kot sova.
} 
Janezu Kebru (2011: 143) iskati v preteklosti, ko so lovci uporabljali čuka kot vabo za vrane. Privezali so ga na kol ali visoko palico, oni pa so med tem streljali na vrane. Del slovenskega frazeološkega fonda je tudi frazem stari čuk, pri katerem izvirni pomen samostalnika čuk, tj. 'čuden, nekoliko omejen človek', še krepi pridevnik stari. Primerjalni frazem grd kot čuk je prav tako motiviran s srditim pogledom in celostno neprijazno podobo čuka. Slovaščina ima na razpolago njegove delne frazeološke ekvivalente, v njihovi sestavi pa se pojavljajo drugi predstavniki živalskega sveta, na primer škaredý ako ropucha (opica), ornitološka sestavina pa se med njimi ne pojavlja.

\section{Frazemi s sestavinami vrana, havran, krkavec - siva (črna) vrana, poljska vrana, krokar}

5.1 Vrana - siva (črna) vrana (lat. Corvus cornix, Corvus corona), havran - poljska vrana (lat. Corvus frugileus) in krkavec - krokar (lat. Corvus corax) so si med seboj zelo podobni in jih ljudje pogosto zamenjujejo, še posebej poljsko in črno vrano, zato imajo tudi podobno simboliko. Zlasti havran - poljska vrana ima bogat, predvsem negativni simbolični pomen. Po Bibliji jo je Noe poslal z barke, da bi po potopu poiskala kopno, prav tako pa je preroku Eliji v puščavo prinesla kruh in meso. V obdobju zgodnjega krščanstva je postala simbol človeka, priklenjenega k posvetnim užitkom, ki odlaga svoje spreobrnjenje. Tudi zato, ker se preživlja z mrhovino in mesom obešencev, je postala „ptica nesreče“, ki naznanja bolezen, vojno in smrt (Biedermann 1992: 87 in 88). V mnogih pravljicah so v podobo vrane prekleti ljudje. V evropskem ljudskem slovstvu lahko podobno kot sraka simbolizira tatu.

5.2 Čeprav sta slovaščina in slovenščina genetsko sorodna jezika, imata v nekaterih primerih različna oziroma drugače razumljena poimenovanja za živalske vrste, kar je lahko vzrok nejasnosti, torej tudi potrebe po preciziranju spornega pojmovnega aparata. Tako je tudi v primeru slovaških poimenovanj vrana, havran in krkavec. Slovaški leksikalni enoti vrana in havran imata namreč v sloveščini ustreznico samo v leksemu vrana, kar smo ugotovili s primerjavo latinskih imen obeh vrst. V kolikor bi torej hoteli $\mathrm{v}$ slovenščino prevesti besedo havran, bi morali uporabiti natančneje opredeljeno besedno zvezo poljska vrana.

Po KSSJ je vrana „večja temna ptica z debelim kljunom, ki živi na poljih“ (KSSJ 2003: 846). Havran je v SSSJ opredeljen kot „velika ptica iz družine ptic pevk z lesketajočim se črnim perjem in z močnim kljunom, podobna črni vrani“, v drugem pomenu „konj, črne barve“, oz. pogosto tudi „ime takega konja“ (SSSJ 2011: 59). Pridevnik havrani pomeni „nanašajoč se na poljsko vrano“ in tudi „ki ima lesketajočo se črno barvo“ (SSSJ 2011: 59). Povratni glagol havraniet' sa ima pomen „lesketati se v črni barvi, zdeti se črn kot poljska vrana“ (SSSJ 2011: 59).

SSKJ opredeljuje vrano kot ,večjo ptico črne ali črno sive barve s spredaj nekoliko ukrivljenim kljunom“ in poljsko vrano kot „,večjo ptico z vijolčastim leskom in vitkejšim kljunom“ (oboje SSKJ 1994: 1539). S samostalnikom vran se označuje samec vrane, včasih pa se lahko tako poimenuje tudi krokar, iz česar je razvidno, da ljudje omenjeni ptici pogosto zamenjujejo. Slovaška ustreznica slovenskega poimenovanja 
morski vran je kormorán, ta beseda pa se za isto ptičjo vrsto uporablja tudi v slovenščini. Slovensko vrstno ime vranja noga je ime za rastlino z belimi, rumenkastimi ali rdečimi cvetovi (lat. Coronopus), v slovaščini vraňonôžka. Pridevnik vran pomeni „črn“, danes pa je ta beseda že zaznamovana $\mathrm{z}$ arhaičnostjo.

Krkavec je po KSSJ „ptica, sorodna vrani, ki se ponavadi prehranjuje z mrhovino“, v prenesenem slabšalnem pomenu tudi ‘človek, ki se okorišča z nesrečo drugih' (KSSJ 2003: 277). SSKJ opisuje krokarja kot „večjo ptico s črnim, kovinsko se svetlikajočim perjem in z debelim kljunom", slabšalno pa leksikalna enota krokar lahko označuje tudi 'človeka, ki napoveduje le kaj slabega, neprijetnega' (oboje SSKJ 1994: 458). Pri zadnjem navedenem pomenu opažamo analogijo z lastnostmi, ki se na Slovaškem pripisujejo čuku (v slovaščini kuvik). V slovenščini obstaja tudi v podobi sinonimnega samostalnika gavran, ki označuje isto ptičjo vrsto, toda le v pesniškem jeziku. Glagol krokati pomeni 'udeleževati se zabave, na kateri se zlasti veliko pije in ki traja pozno v noč' (SSKJ 1994: 458), krokar je torej tudi človek, ki kroka.

5.3 Omenjene negativne konotacije, ki so povezane s črno in poljsko vrano, se niso enako intenzivno in plastično odražale $\mathrm{v}$ frazeologijo, kjer se večinoma kaže samo njuna črna barva, zlasti v slovaščini, primerjaj slovaške frazeme čierny ako havran, mat' vlasy (oči) <čierne> ako havran, havranie vlasy ali slovenski frazem črn kot vran. V obeh opazovanih jezikih obstaja besednozvezni frazem z odvisno samostalniško zvezo biela vrana - bela vrana. ${ }^{12}$ SSJ ga definira kot 'redek pojav, redkost' (SSJ 1965: 160), po SSF gre za 'veliko redkost, izjemo, posebneža' (SSF 2011: 1063). Slovenščina pozna tudi frazem obirati se (vleči se) kot mokra vrana v pomenu 'zelo počasi, brez energije se premikati'.

Po ustnem ljudskem izročilu vrane, predvsem pa krokarji, naj ne bi skrbeli za svoje mladiče, kar je motiviralo nastanek slovaškega frazema krkavčia matka, torej 'neskrbna, slaba (predvsem taka, ki je umorila svojega otroka)' (SSJ 1959: 775), dandanes pa se pojavlja tudi v obliki krkavči otec, krkavčí rodičia. V slovenščini takšne ustreznice nismo našli. ${ }^{13}$

\section{Frazemi s sestavino straka - sraka}

6.1 Znano je, da posamezne kulture simbolov ne dojemajo enako. V Evropi strakasraka (lat. Pica) simbolizira opravljivost in tatvino, na Kitajskem pa predstavlja srečo, je znanilka dobrih vesti ali prijetnih gostov (Biedermann 1992: 286).

Po KSSJ je straka, „črno-bela ptica z dolgim repom in rezkim glasom, preneseno simbol tatu“ (KSSJ 2003: 709). SSKJ srako opiše kot „ptico s črnim in belim perjem in dolgim repom“, v drugem, ekspresivnem pomenu pa označuje osebo, ki 'govori s

\footnotetext{
12 Na osnovi te karakteristike se na Slovaškem podeljuje nagrada za družbeno koristno in pogumno dejanje, ki se imenuje Biela vrana, Biela vrana se prav tako imenuje tekmovanje doma varenih pivskih specialitet. V Sloveniji je bila v 60. in 70. letih 20. stoletja popularna glasbena skupina Bele vrane.

13 Slovenski stavčni frazem vrana je komu izpila možgane se uporablja v pomenu 'nekdo je znorel, zmešalo se mu je'.
} 
kričavim, neprijetnim glasom' (SSKJ 1994: 1294). V slovenščini se lahko pojavlja tudi kot psovka, toda ne v pomenu 'tat'.

Poimenovanje stračia nôžka $\mathrm{v}$ slovaščini označuje strupeno poljsko rastlino iz družine iskernikovité (lat. Delphinium) ${ }^{14}$ (SSJ 1964: 268), v slovenščini ostrožniki. Slovenski izraz sračja noga je v nekaterih, na primer primorskih narečjih, pomenil narisan oz. izrezljan simbol, ki naj bi služil za odganjanje more.

6.2 V slovaščini in slovenščini obstaja popoln frazeološki ekvivalent kradnút ako straka - krasti kot sraka. Ta primerjava odraža dejstvo, da imajo srake rade lesketajoče se, bleščeče predmete, ki si jih pogosto prinašajo v svoja gnezda, kar v obeh jezikih izraža stalna besedna zveza straka zlodejská - tatinska sraka. Nagle, ponavljajoče se zvočne sekvence, s katerimi se sraka oglaša, so v slovaščini motivirale nastanek frazema rapotat' ako straka v pomenu 'hitro in veliko govoriti' in 'govoričiti' (SSJ 1964: 268). Slovenski primerjalni frazem dreti se (kričati, vpiti, vreščati) kot sraka nakazuje bolj oster, pronicljiv in neprijeten glas srake. V slovenščini obstaja njegova narečna metaforično-metonimična glagolska okrajšava sračiti se, ki nosi pomen 'dreti se', pa tudi 'postavljati se, bahati se' (SSKJ 1994: 1294). Starejši slovaški frazem ukazovat' (mal'ovat') niekomu straku na kole izraža prenesene pomene 'lagati, goljufati nekoga, obljubljati nemogoče, neresnične stvari' (SSJ 1964: 268), njegova skrajšana podoba straka na kole se nanaša na pomen 'lažniva stvar, iluzija, izmišljotina, neresničnost' (SSJ 1964: 268). SSJ pri starejšem primerjalnem frazemu pozerat' ako straka navaja pomen 'gledati poželjivo, hoteče, zvedavo' (SSJ 1964: 268).

Sračje gnezdo pomeni v slovenščini 'nekaj neurejenega ali kaotičnega', kar zrcali človekovo opažanje, da je sračje gnezdo v primerjavi z gnezdi drugih ptic zgrajeno zanemarjeno, neurejeno. S tem izrazom lahko označimo karkoli, kar je neurejeno, kaotično, slabo organizirano ali celo nelogično. Primerjava stanovanje kot sračje gnezdo analogno nakazuje na nered v stanovanju. Če ima nekdo na glavi sračje gnezdo - stračie hniezdo, ima 'razmršene, nepočesane lase'. V slovaščini slabšalni izraz stračie hniezdo tudi označuje 'nekaj neurejenega (zlasti frizuro)' (SSJ 1959: 491). Slovaščina pozna v tem pomenu poleg frazema stračie hniezdo tudi sestavinsko varianto vrabčie hniezdo.

\section{Frazemi s sestavinama holub, hrdlička - golob, grlica}

7.1 Holub - golob (lat. Columba) oz. holubica - golobica sta imela že od nekdaj $\mathrm{v}$ številnih kulturah bogat simbolični pomen. Zaradi navidezno prijateljskega in miroljubnega značaja sta simbol nežnosti, ljubezni, utelešata pa tudi plahost, bojazljivost, hrdlička - grlica celo tudi klepetavost. Po Bibliji simbolizira golobica konec potopa, saj je v kljunčku prinesla Noetu v barko oljčno vejico (Biedermann 1992: 91). V podobi golobice so upodabljali Svetega duha, pa tudi dušo, ki leti v raj. Biedermann (1992: 92) navaja, da se v zgodnjekrščanskem spisu Physiologus omenja grlica, ki, čeprav je po naravi klepetava, se po smrti svojega druga nikoli več na nikogar ne naveže, spominja

$14 \quad$ Kultivirana vrsta Delphinium cultorum se goji kot okrasna rastlina na vrtovih. 
se na mrtvega druga in kmalu tudi sama umre. Prav zaradi tega je grlica tudi simbol velike ljubezni in zvestobe.

Holub je po SSSJ ,ptica (pogosto sive barve) iz družine golobov, ki je rejena $\mathrm{v}$ mnogih pasmah ali divje živeča." (SSSJ 2011: 135). Znana je tudi leksikalizirana zveza poštový holub, asfaltové holuby so 'koluti, uporabljani kot tarče v športnem streljanju' (SSSJ 2011: 135). Pomanjševalna oblika holúbok ni oznaka samo za majhnega goloba, ampak je tudi ljubkovalno ime za drago osebo, z besedo holúbkovia lahko označimo 'par zajubljencev'. V slovaškem vojaškem žargonu je holub poimenovanje za 'novinca, začetnika' (SSSJ 2011: 135), v tem pomenu pa se uporablja tudi sopomenka bažant. ${ }^{15}$ Pomanjševalni obliki ženskega spola holubička, holubienka sta ljubkovalni poimenovanji za 'dekleta ali ženske'. Mleto meso, ki je zavito v zeljne liste, se v nekaterih slovaških narečjih imenuje holúbky. Pridevnik holubi ima poleg pomena „nanašajoč se na goloba“" tudi pomen 'siv, ki ima barvo kot golob perje' (oboje SSSJ 2011: 135). Pridevnik holubiči pomeni 'miren, neagresiven, miroljuben' (SSSJ 2011: 135). Prostor za rejo golobov je holubník, toda v prenesenem pomenu tudi 'kraj, zgradba, kamor in od koder se brez reda, neorganizirano, prostovoljno prihaja in odhaja' (SSSJ 2011: 136), torej nekaj, kar deluje zelo kaotično. SSSJ navaja tudi glagol holúbkovat'sa, torej 'nežno se vesti drug do drugega, ljubkovati se' (SSSJ 2011: 136).

Po SSKJ je golob „domača ali divja ptica z majhno glavo, kratkim vratom in krepkim telesom“(SSKJ 1994: 246). V slovenščini obstaja tudi leksikalizirana besedna zveza poštni golob in tudi golob pismonoša. Morski golob (lat. Myliobatis) je vrsta velike morske roparske ribe s strupeno bodico na repu, glinasti golob pa je krožnik, ki se, kot smo že omenili, uporablja kot gibljiva tarča za strelce. Dragega človeka lahko ljubkovalno nagovorimo s samostalniki golobček, golobče, golobica, golobičica, golobička, golobka, pri čemer golobica, golobičica in golobička označujejo poleg samice goloba tudi 'mlado, prijazno žensko'. Golobica je tudi goba s krhkim mesom in z živo pisanim klobukom, v slovaščini plávka. Glagol golobčkati se pomeni 'poljubljati se, ljubkovati se' (SSKJ 1994: 246). Pridevnik golobji izraža tudi 'prijaznost in krotkost', enako kot njegova slovaška ustreznica holubičí.

7.2 $\mathrm{Hrdlička}^{16}$ (lat. Streptopelia) je po SSSJ ,ptica iz družine golobov z vitkim telesom in majhno glavo, ki je podobna golobu, značilna po svojem gruljenju“"(SSSJ 2011: 174). SSKJ grlico opiše kot „golobu podobno ptico z rdečimi nogami“ (SSKJ 1994: 262). Samostalnik grlica lahko v prenesenem pomenu označuje tudi ‘žensko', zlasti lepo in prijazno. V slovaščini obstaja tudi glagol hrdličkovat' sa z identičnim pomenom kot holúbkovat' sa, torej 'nežno si izkazovati ljubezen, ljubkovati se' (SSSJ 2011: 174).

7.3 Dejstvo, da je golob simbol miru, se je odražalo tudi v stalni besedni zvezi holubica mieru s slovensko ustreznico golob miru, redkeje tudi golobica miru. Frazem byt' nadutý ako holub se uporablja v pomenu 'biti zelo napihnjen', ni pa motiviran $\mathrm{z}$

\footnotetext{
15 V slovenščini dobesedno fazan.

16 Ime Grlica nosi tudi slovenska založba, prav tako se Grlica imenuje časopis, ki se ukvarja z mladinskim zborovskim petjem.
} 
značajem goloba, ampak z njegovo podobo, ko na prsih našopiri perje, kar deluje napihnjeno. Primerjalni frazem byt' sivý (biely, šedivý) ako holub je večinoma povezan z označevanjem barve las starejših moških, podobno kot frazem obeliet' ako holub, torej 'popolnoma osiveti'. Omenjena mirnost, miroljubnost, neagresivnost, včasih kar pasivnost golobov oziroma golobic je motivirala nastanek stalnih besednih zvez holubičia povaha (nátura), holubiči národ, s katerimi se pogosto označujejo Slovaki. Slovaški primerjalni frazemi zit' $<$ si $>$ ako dva holuby (holúbky, hrdličky), mat' sa radi ako dva holúbky, hrkútat' $<$ si $>$ ako dva holúbky, žit'<si> (naživat' $<s i>)$ ako $<d v e>$ holubičky (holúbky, hrdličky), žit'<si> ako pár holúbkov, žit' $<$ si $>$ ako holub s holubicou s semantiko 'zelo se ljubiti, živeti skupaj v ljubezni in složnosti' (SSSJ 2011: 135) imajo v slovenščini ustreznico samo v frazemu živeti kot dva golobčka (HSRPF 2006: 184). Primerjava smiat' sa ako hrdlička je bila motivirana s prijetnim, žametnim glasom grlice in ima pomen 'lepo se smejati' (SSJ 1959: 522), njena slovenska ustreznica je primerjalni frazem smejati se kot grlica. Drugih slovenskih frazeoloških enot ali leksikaliziranih zvez s sestavinama golob in grlica nismo našli.

\section{Frazemi s sestavino dudok - smrdokavra}

8.1 Dudok-smrdokavra (lat. Upupa ${ }^{17}$ se je pogosto pojavljala v folklori in mitologiji antičnih kultur, pri čemer so se ji pripisovale ambivalentne lastnosti. V Egiptu je bila sveta ptica, pogosto upodobljena kot okrasje na žezlih bogov. Za Skandinavce je pomenila znanilko vojne, drugje v Evropi pa je bila pogosto označevana za tatu ali za nečisto ptico, ker je izkopavala ličinke iz gnoja, zato je v srednjeveških bestiarijih simbolizirala grešnika, ki okuša blato greha (Biedermann 1992: 66). Slovensko poimenovanje smrdokavra je zloženka glagola smrdeti in narečne leksikalne enote kavra (vrana) (Snoj 1997: 586). To poimenovanje je najverjetneje dobila zato, ker se je že od antičnih časov naprej o njej neupravičeno trdilo, da ima umazano gnezdo in da smrdi, kar pa se pravzaprav nanaša na obrambni mehanizem smrdokavre, ki ga uporablja zlasti v obdobju, ko samica gnezdi in s smradom brani svoje gnezdo ter mladiče.

Po SSSJ je dudok „rumenorjav ptič s črno-belimi črtami na zgornjem delu telesa, z dolgim, tankim kljunom in pahljačasto perjanico na glavi“" (SSSJ 2006: 808). Tudi SSKJ to ptico opiše podobno, saj prav tako poudarja perjanico na glavi (SSKJ 1994: 1254), ki je najizrazitejša značilnost smrdokavre, zaradi katere je ni mogoče zamenjati $\mathrm{z}$ drugo ptico.

8.2 Čeprav gre za zelo zanimivega predstavnika iz ptičjega sveta, je presenetljivo, da v slovaščini obstaja več frazemov s sestavino dudok, medtem ko v slovenščini nismo našli niti enega samega frazema s sestavino smrdokavra. V slovaščini so to primerjalni frazemi nafúkaný ako dudok 'zelo namrščen, jezen', sediet' ako dudok s podobnim pomenom 'sedeti namrščeno, nepremično, pasivno' (SSSJ 2006: 808). Oba frazema očitno izvirata iz videza smrdokavre, ki, sedeča z našopirjenim perjem in izrazito perjanico

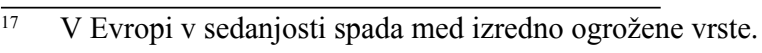


na glavi, ne deluje preveč prijateljsko, vljudno in veselo. Primerjalni frazem spat' ako dudok $\mathrm{v}$ pomenu 'togo, trdno spati' ima $\mathrm{v}$ slovenščini delne ustreznice $\mathrm{v}$ frazemih: spati kot polh, spati kot top, spati kot klada, spati kot zaklan. Slovaški frazem je domnevno povezan z že omenjenim obrambnim mehanizmom samice smrdokavre - kljub smradu, $\mathrm{s}$ katerim brani gnezdo, lahko v njem brez težav spi skupaj s svojimi mladiči.

Slovaški zastareli leksem dudky je šaljivo poimenovanje za 'denar'. Anton Bernolák v svojem Slowárju (1825, s. 512) navaja: *Dudek: Má Dudki: est nummatus, habet pecunias, nummos: er hat viel Geld: péznes ember, vagyon pénze. $\mathrm{V}$ tem pomenu je verjetni izvor primerov iz slovaške književnosti 19. stoletja, v kateri se je beseda $d u$ dok pojavila tudi v pomenu plačilnega sredstva: Dal som zaň červený dudok (J. Záborský); A čo je hlavné, má dudky (G. K. Zechenter-Laskomerský). ${ }^{18}$

\section{Frazemi s sestavino žlna - žolna}

9.1 Po KSSJ je žlna (lat. Picus) ,gozdna ptica rumeno zelene barve, podobna detlu“ (KSSJ 2003: 983). SSKJ žolno opiše kot „ptico z močnim dletastim kljunom in nogami, prilagojenimi za plezanje po deblu“", naveden pa je tudi pomen 'kdor dosti, pogosto pije' (alkoholne pijače), in sicer z oznako ekspresivno (SSKJ 1994: 1710). Leksikalna enota žolna je lahko tudi psovka za pijanega človeka.

9.2 V slovaškem frazeološkem fondu se ornitološka sestavina žlna ne pojavlja. V slovenščini obstaja primerjalni frazem, ki je povezan z že omenjenim drugim pomenom leksikalne enote žolna, in sicer piti kot žolna (SSF 2011: 1115), HSRPF ga navaja tudi v podobi pijan kot žolna (2006: 300). V tem primeru lahko govorimo o bogatem sopomenskem nizu frazemov, ki ilustrirajo čezmerno uživanje alkoholnih pijač in imajo $\mathrm{v}$ vseh jezikih bogato zastopanost, ${ }^{19}$ čeprav motivacija njihovega nastanka ni vedno razvidna. Janez Keber v SSF razlaga morebiten nastanek primerjalnega frazema piti kot žolna preko samostalnika pivka, ki se uporablja za sivo žolno (lat. Picus canus), in sicer na osnovi glasu piv-piv, s katerim se oglaša. Glagol pivkati se uporablja v pomenih 'oglašati se z glasom piv-piv' in tudi 'pomalo piti', s samostalnikom pivka ne označujemo samo ptice, ampak tudi žensko, ki, 'pije, uživa pijačo', navadno ekspresivno pa tudi ‘žensko, ki (rada) pije alkoholne pijače'. Po J. Kebru (2011: 1155) je primerjava piti kot žolna nastala s sovpadanjem teh pomenov, čeprav žolne ni mogoče povezovati s prekomernim uživanjem alkohola. Marko Snoj (2013: 94) navaja - poleg omenjene razlage - še dve možnosti za nastanek frazema. Po Snojevem mnenju gre lahko za delni kalk nemškega izraza Schluckspecht, ki je zloženka glagola schlucken (požirati, goltati) in samostalnika Specht (žolna). Po tretji domnevi utegne biti „frazem piti kot žolna prenarejen iz *piti kot žolnir, pri čemer je beseda žolnir izposojenka iz srednje-

\footnotetext{
18 Primerjaj Pavol Žigo (2013: 15).

19 Na primer slovaški frazemi pit' ako čík, pit' ako Rus, pit' ako dúha, opit'sa ako cecok, opitý ako bočka, opitý ako čap, opitý ako delo (snop), opitý ako < divé> zviera, opitý ako hovädo (dobytok), opitý ako klát, opitý ako sviňa (prasa), opitý ako tel'a (sysel'), v slovenščini na primer piti kot krava, piti kot goba, pijan kot živina, pijan kot mavra, pijan kot klada, pijan kot dila, pijan kot čep itd.
} 
visokonemške solner, kar pomeni ‘vojak', mlajše tudi 'inženir'“. Po Snoju niti ene od omenjenih možnosti ni mogoče z gotovostjo dokazati, njemu samemu pa se zdi najbolj verjetna druga razlaga.

\section{Zaključek}

$\mathrm{Na}$ osnovi analize slovaških in slovenskih frazemov, ki vsebujejo leksikalne enote vták, vtáčik, vtáči : ptič (ptiček), ptičji in najpogostejše ornitološke sestavine, ki se nanašajo na vrste ptic, živeče $\mathrm{v}$ naravi, lahko ugotovimo, da je njihova zastopanost $\mathrm{v}$ obeh jezikih izredno velika in raznolika. V nekaterih primerih gre za internacionalne frazeme, ki imajo izvir v antični kulturni dediščini, naprimer nosit'sovy do Atén - nositi sove $v$ Atene. V drugo skupino spadajo popolni ekvivalenti, ki so nastali na osnovi empiričnih izkušenj in identičnih asociacij obeh jezikovnih skupnosti, na primer hladiet' ako sova - gledati kakor sova; kradnút' ako straka - krasti kot sraka; smiat'sa ako hrdlička - smejati se kot grlica; nočný vták - nočni ptič; biela vrana - bela vrana; sračje gnezdo - stračie hniezdo itd. Z vidika primerjalne slovaško-slovenske frazeologije se kot najbolj zanimivi kažejo delni ekvivalenti tipa ne tič ne miš - ani ryba, ani rak ali grd kot čuk - škaredý ako ropucha (opica), še posebej pa enote, ki v enem od obravnavanih jezikov nimajo frazeološke ustreznice, kot so na primer slovaški frazemi $u k a z o v a t '$ (mal'ovat') niekomu straku na kole, krkavčia matka, krkavči otec, krkavči rodičia in tudi enote z nejasno motivacijo nastanka, na primer slovenski frazem piti kot žolna.

Na koncu je potrebno dodati, da naš prispevek prinaša le delčke podatkov iz širokega spektra nadaljnjih morebitnih raziskav o obstoju ornitoloških sestavin v slovaškem in slovenskem frazeološkem fondu. Ugotovili smo tudi njihovo bogato zastopanost $\mathrm{v}$ paremioloških enotah, pa tudi to, da se nekatere vrste ptic, na primer orel ali sokol, ki imata $\mathrm{v}$ slovaškem in v slovenskem ustnem ljudskem slovstvu nenadomestljivo simbolično vlogo, kot sestavini $v$ frazemih skoraj ne pojavljata. Te, pa tudi druge bele lise na področju slovaško-slovenskega frazeološkega raziskovanja, ponujajo mnoge navdihe za do danes še neobdelano temo.

\section{LITERATURA}

Biedermann, Hans. 1992. Lexikón symbolov. Bratislava: Obzor.

Čižmárová, Mária. 2001. Ekvivalenčné typy frazém v ukrajinčine a slovenčine. Slavica Slovaca. 2: $114-120$.

Gantar, Polona. 2013. Slovar slovenskih frazemov in sodobna slovenska frazeologija. V: Frazeološka simfonija: Sodobni pogledi na frazeologijo. Jakop, Nataša; Jemec Tomazin, Mateja (red.). Ljubljana: Inštitut za slovenski jezik Frana Ramovša. 145-156.

Jakše, Darija. 2001. Najbolj razširjene žuželke v primerjalnih frazemih v slovenščini in slovaščini. V: Philologica LIII. Zbornik Filozofickej fakulty Univerzity Komenského. Pančíková, Marta (red.). Bratislava: Univerzita Komenského. 213-223. 
Keber, Janez. 1996. Živali v prispodobah 1. Celje: Mohorjeva družba.

Keber, Janez. 1998. Živali v prispodobah 2. Celje: Mohorjeva družba.

Keber, Janez. 1999. Živalske metafore kot vir za imena, vzdevke in priimke. Jezikoslovni zapiski. 5: 135-149.

Keber, Janez. 2001. Razlaganje izvora slovenskih frazemov. V: Skripta 5. Zbornik za učitelje slovenščine kot drugega/tujega jezika. Kržišnik, Erika (red.). Ljubljana: Center za slovenščino kot drugi/tuji jezik pri Oddelku za slovanske jezike in književnosti Filozofske fakultete Univerze v Ljubljani. 35-50.

Kocbek, Fran; Šašelj, Ivan. 1934. Slovenski pregovori, reki in prilike. Celje: Družba Sv. Mohorja v Celju.

Krošláková, Ema. 1997. Frazeologické prirovnania so zoonymickým komponentom. V: Frazeolofické štúdie II. Durčo, Peter (red.). Bratislava: Esprima. 103-112.

Kržišnik, Erika. 2004. Poskusni zvezek slovenskega frazeološkega slovarja. Slavistična revija. 2: 199-208.

Kržišnik, Erika. 2000. Biblične stalne besedne zveze v Slovarju slovenskega knjižnega jezika in v slovenskem jeziku. V: Razprave/Dissertationes XVII. Toporišič, Jože (red.). Ljubljana: Slovenska akademija znanosti in umetnosti. Razred za filološke in literarne vede. 67-79.

Mečiarová, Barbora. 2003. Zoonymické komponenty pes a mačka v slovenskej a bulharskej frazeológii. V: BraSlav 1/2002. Žigo, Pavol (red.). Bratislava: Univerzita Komenského. 265-269.

Petermann, Jürgen; Kržišnik, Erika. 2004. Janez Keber: Frazeološki slovar slovenskega jezika. Poskusni zvezek. Slavistična revija. 3: 345-352.

Snoj, Marko. 2013. Frazemi v luči etimologije: Metoda in praksa. V: Frazeološka simfonija: Sodobni pogledi na frazeologijo. Jakop, Nataša; Jemec Tomazin, Mateja (red.). Ljubljana: Inštitut za slovenski jezik Frana Ramovša. 145-156.

Škultéty, Jozef. 1989. Názvy cicavcov v slovenských ustálených prirovnaniach. Slovenská reč. 5. Bratislava: 267-275.

Záturecký, Adolf Peter. 2005. Slovenské príslovia, porekadlá, úslovia a hádanky. Bratislava: Slovenský Tatran.

Žigo, Pavol. 2013. A bullitu ad Upupam. V: Philologica LXXI. Zborník Filozofickej fakulty Univerzity Komenského. Dobríková, Mária (red.). Bratislava: Univerzita Komenského. 13-16.

\section{SLOVARJI}

Fink Arsovski, Željka et al. 2006. Hrvatsko-slavenski rječnik poredbenih frazema. Zagreb: Knjigra. [HSRPF]

Keber, Janez. 2011. Slovar slovenskih frazemov. Ljubljana: Založba ZRC, ZRC SAZU. [SSF]

Smiešková, Elena. 1988. Malý frazeologický slovník. Bratislava: Slovenské pedagogické nakladatel'stvo. [MFS] 
Snoj, Marko. 1997. Slovenski etimološki slovar. Ljubljana: Mladinska knjiga. [SES]

Krátky slovnik slovenského jazyka. 2003. Kačala, Ján; Pisárčiková, Mária; Považaj, Matej (red.). Bratislava: Veda. [KSSJ]

Slovar slovenskega knjižnega jezika. 1994. Bajec, Anton et al. Ljubljana: DZS. [SSKJ]

Slovnik slovenského jazyka. 1959-1968. Peciar, Štefan (red.). Bratislava: Vydavatel'stvo Slovenskej akadémie vied. [SSJ]

Slovnik súčasného slovenského jazyka A-G. 2006. Buzássyová, Klára; Jarošová, Alexandra (red.). Bratislava: Veda. [SSSJ]

Slovnik súčasného slovenského jazyka H-L. 2011. Buzássyová, Klára; Jarošová, Alexandra (red.). Bratislava: Veda. [SSSJ]

Slovar slovenskih frazemov. 2011. Keber, Janez. Ljubljana: Založba ZRC, ZRC SAZU. [SSF]

\section{SPLETNI VIRI}

Gigafida: Korpus slovenskega jezika. http://www.gigafida.net

\section{RESUMÉ}

\section{VTÁČí SVET VO SVETLE SLOVENSKEJ A SLOVINSKEJ FRAZEOLÓGIE}

V príspevku sa analyzujú slovenské a slovinské ustálené spojenia, v ktorých komponentovom zložení sa vyskytujú pomenovania jednotlivých druhov vtákov žijúcich vo vol'nej prírode v miernom podnebnom pásme, v ktorom ležia i Slovensko a Slovinsko. Do výskumu sú okrem základných pomenovaní zahrnuté aj ich derivované adjektívne a slovesné tvary. Autorka sa zmieňuje i o symbolike, ktorej nositel'mi sú jednotlivé druhy vtákov, ked’že táto zohráva často dôležitú úlohu pri vysvetl'ovaní motivácie vzniku frazém. V d’alšej časti sleduje výskyt skúmaného typu komponentov vo vol’ných, terminologických a lexikalizovaných slovných spojeniach a porovnáva ich zastúpenie vo frazémach na základe významovej (obsahovej) zhody, t. j. z hl'adiska frazeologickej ekvivalencie. Konštatuje, že zastúpenie frazém s takto vymedzenými komponentmi je v oboch jazykoch vel'mi početné a rôznorodé a že z hl'adiska porovnávacej slovensko-slovinskej frazeológie sú najzaujímavejšie prípady parciálnej ekvivalencie, ale najmä jednotky, ktoré v jednom zo sledovaných jazykov nemajú frazeologický náprotivok.

Kl’účové slová: frazéma, slovenská frazeológia, slovinská frazeológia, frazeologický komponent, frazeologická ekvivalencia 
